\title{
Tree Species Diversity and Their Potential Uses in Kizee Village Forest Reserve, Tanzania
}

\author{
Joshua Maguzu, Mathew Mndolwa, Nancy Eliad Pima*, Franklin Bomani, Pray Solomon
}

Tanzania Forestry Research Institute, Morogoro, Tanzania

Email address:

nancypima@yahoo.com (N. E. Pima)

${ }^{*}$ Corresponding author

\section{To cite this article:}

Joshua Maguzu, Mathew Mndolwa, Nancy Eliad Pima, Franklin Bomani, Pray Solomon. Tree Species Diversity and Their Potential Uses in Kizee Village Forest Reserve, Tanzania. Agriculture, Forestry and Fisheries. Vol. 6, No. 2, 2017, pp. 59-65. doi: 10.11648/j.aff.20170602.12

Received: January 25, 2017; Accepted: March 11, 2017; Published: April 1, 2017

\begin{abstract}
Tree species diversity and their potential uses were assessed in Kizee Village Forest Reserve, Muheza District. Household survey, focus group discussions, key informant interview and tree diversity surveys were used during data collection. Data were analyzed both qualitatively and quantitatively using the Statistical Package for Social Science. Tree species diversity was computed using Shannon-Wiener diversity index. A total of 32 tree species from 20 families with different uses were identified. The most dominant tree species identified was Albizzia antihelmintica which contributed $19.83 \%$ of all tree species. The forest is a potential source for timber, charcoal, firewood, fodder, medicinal plants/trees and poles. Small diameter class trees $(\leq 15 \mathrm{~cm})$ contributed $63.1 \%$ of all standing trees. The forest had stem density of 434 stems $\mathrm{Ha}^{-1}$ and Shannon-Winner Diversity Index of 2.2717 which were biologically within the normal tree diversity status. Majority $(70 \%)$ of the respondents were aware of types of tree species available in the forest. The index obtained showed a relative achievement of forest policy of improved forest quality and stable forest community. However, more attention is needed to make sure that the forest is not degraded.
\end{abstract}

Keywords: Tree Species Diversity, Potential Uses, Kizee Village Forest Reserve

\section{Introduction}

Forests are important in the livelihoods of local people in most developing countries. Wherever forests are myriad of goods and services, offered to the respective society for improvement of communities' welfare. Local people depend on forests resources such as trees for various products such as energy, construction materials, furniture, medicine, food, agricultural implements and utensils $[1,2]$. These resources provide not only products, but also ecological services which are relevant to the livelihoods of the people, i.e. soil protection, soil fertility, water regulation, micro-climate and carbon sequestration for mitigating global warming [2]. Thus, trees are of importance to the local peoples' lives, households' economy, conservationist and national economy at large [3]. This is because, myriad of goods and services are offered to the respective society for improvement of communities' welfare. In Tanzania forests and woodlands are categorized in different management forms. These include forest on public lands, Government Forest Reserves, and private and community forests [4]. Longterm management of forest ecosystems requires a detailed understanding of both the resources contained in the forest, as well as forest dynamic processes over time.

Trees harvested from forests and woodlands have been commonly put in various uses. The use depends mainly on time, location and culture of particular community. However, communities' requirements have been changing with time. There have been a lot of changes in terms of taste, sizes and qualities of different products accrued from the forest including trees. This has been contributed by a number of factors. For example, increase in population and improved technology brought about more variation in intensity and uses of trees and shrubs [5]. Trees which were formally considered not useful in terms of size and quality are presently been consumed and priorities kept on differing from place to place. At the same time, because of diminishing quantities of trees, 
some trees which had one or two specific uses are now found to have new and sometimes other multiple uses. This big range of tree uses brings about difficulties in management as no one tree has hardly only one specific use. Practically this can be made much easier by putting tree uses in groups as reflected by their uses and benefits. Mbuya et al. [6] identified five (wood, food, fodder, environment and other uses) tree use groups. Because of difficulties in grouping, it is consequently difficult to categorize or prioritize uses of the same tree. It is accepted that the priority use of a particular tree in one community may not be the same in another community [5] making the tree use almost site specific.

Biodiversity directly affects human life. Beyond production of food, fibre, fuel and income, biodiversity plays an important role in nutrient cycling, control of microclimates, regulation of hydrological process and abundance of undesirable microorganisms and detoxification of noxious chemicals [6]. Biodiversity not only contributes to material welfare and livelihoods but also contributes to security, resiliency, social relations, freedom of choice and actions [8]. Biodiversity information is very important in providing baseline information on the biological values of the forests for management planning and monitoring, and to train field staff in the use of biological inventory techniques [9]. Some biodiversity studies have been conducted in various areas in Tanzania. Example of these areas is the Eastern Arc [10]. It was noted that the coastal belt did not receive much research attention [11]. However, information on trees diversity and their potential uses is lacking in many forests and especially in traditionally managed forests. To ensure good management and sustainable productivity within natural forests, one needs to know the priority use of different trees and their diversity in the respective area. At the same time, to avoid the use of peoples' perceptions it is necessary to conduct inventory which will be used as baseline for assessment of the effectiveness of the management systems. This is because; management of natural forests depends on information available on the growing stock [12]. This study focused on tree species diversity and their potential use in Kizee Village Forest Reserve, Muheza District, Tanzania.

\section{Materials and Method}

Muheza District is located in north-east Tanzania, bordering Tanga City on the North East, Mkinga on the North, Pangani in the South and Korogwe District in the West. It lies between $5^{\circ} 0^{\prime} 0^{\prime \prime} \mathrm{S}$ and $38^{\circ} 57^{\prime} 45^{\prime \prime} \mathrm{E}$. The climate is characterized by short rains from October - December and long rains from March-May with annual rainfall ranging from 1,100 to $1,400 \mathrm{~mm}$ per annum. The minimum and maximum temperatures are $24^{\circ} \mathrm{C}$ and $30^{\circ} \mathrm{C}$, respectively. The district had total population of 204,461 people [13] where the main ethinic groups were Bondei (16.5\%), Sambaa (15.8\%), Digo (13.8\%), Zigua (6.8\%), Segeju (6.1\%), Makonde
(5.6\%) and others (35.4\%). Farmers make the larger proportion $(96 \%)$ of the population in the study area. The food crops grown are cassava, maize, banana, pigeon peas and vegetables for food while coconut trees, oranges and cashew nuts grown for cash. In Muheza District, the East Usambaras contain four Village Forest Reserves (Kizee, Kizangata, Mfundia and Handei), and two private forests (Magoroto and Kwamtili). The study was carried out at Kizee Village Forest Reserve (KVFR) which occupy 39.4 ha within Mwarimba and Misozwe villages, Misozwe ward in Muheza District-Tanga Region.

Purposive sampling technique was employed in selecting two villages (Mwarimba and Misozwe) surrounding KVFR. The selection was based on proximity to the forest. Random selection of household within each identified villages was done. A total of 30 household individuals from each village irrespective of village population size were selected. Data were collected using Participatory assessment, household survey and forest tree resource assessment. Household survey was conducted using structured questionnaire to complement the qualitative information from participatory assessment. A total of 60 households were randomly selected from two villages. Questionnaires were used to collect data related to; identification of tree species and the potential uses in the study area. Participatory assessment included Focus Group Discussion (FGD) and Key informant interview. FGDs aimed at capturing information on tree species and their potential uses to livelihoods. FGDs comprised of $10-15$ people in each village, aged above 40 years with gender consideration. The key informants were drawn from groups of people with special knowledge in various tree species like the elders, local herbalists and stakeholders participating in management of the reserve and who are familiar with the forest ecosystem in question.

The assessment of forest tree resource was done through forest inventory to understand tree species diversity, their distribution and estimate the available stock. The actual inventory was preceded by a reconnaissance survey which involved establishing transects and plot laying-out on the map of the forest reserve. Systematic sampling design was adopted in order to cover the whole forest area and variation between vegetation cover. This study adopted a sampling intensity of $0.1 \%$. Synnot [14] recommended sampling intensity within a range of $0.5 \%$ to $0.7 \%$ for tropical natural forest inventories but can be as low as $0.01 \%$ [15].

A total of 20 quadrants $\left(400 \mathrm{~m}^{2}\right)$ were laid equidistantly along the transect running across the contours from North South direction. In each quadrant, all trees with a diameter at breast height (DBH, $1.3 \mathrm{~m}$ above the ground) of $\geq 5 \mathrm{~cm}$ were measured and identified by species. The DBH was measured using a DBH tape. In the field, each tree was identified in local name and confirmed into botanical name. The information that was recorded from each quadrant included: tree species names, regenerants frequency, indicators of human disturbances such as trees cut, poles cut, charcoal kilns, pit sawing, burnt areas and grazing.

Both qualitative and quantitative information's were 
analyzed using Statistical Package for Social Science (SPSS) computer software tools. Qualitative information collected through verbal discussion and open ended questionnaires were broken down into smaller meaningful themes and analyzed to bring statistical meaning. Data were explored for distribution of responses and central tendency (means, percentage and frequencies). The identified number of trees by households was ranked according to priority uses of each tree species mentioned. The highest priority was ranked 6 and reduced in values down to 0 for unknown specific use. Tree species diversity was computed using Shannon - Wiener Diversity Index (SD) [17].

The Shannon - Wiener Diversity Index was denoted by;

$$
\mathrm{H}=-\sum_{\mathrm{i}=1}^{\mathrm{s}} \mathrm{Pi} \ln \mathrm{Pi}
$$

\section{Where}

$\mathrm{s}=$ The number of species,

$\mathrm{Pi}=n \mathrm{n} / \mathrm{N}, \mathrm{ni}=$ total number of individuals in the $\mathrm{i}^{\text {th }}$ species

$\mathrm{N}=$ Total number of individuals of all species.

\section{Results and Discussion}

\subsection{Forest Structure}

\subsubsection{Species Composition and Diversity}

There were thirty two (32) tree species identified at KVFR belonging to twenty (20) families with different uses (Table 1). Family Fabaceae contributed the greatest fraction over the other families. Other important families included Anacardiaceae, Araliaceae, Burseraceae, Boraginaceae, Bignoniaceae, Caesalpiniodeae, Combretaceae, Compositae, Euphobiaceae, Euphobiaceae, Malvaceae, Moraceae, Sapotaceae, Sterculiaceae, Sapindaceae, Polygalaceae, Rutaceae, Taccaceae and Tiliaceae. Number of families recorded was relatively small. This was likely due to small size of the forest [8]. When studying vegetation structure and composition of the Taita Hills Forests, Wilder [16] found similar number of species in Ngagao forest (32 species). Wilder [16] further reported even a smaller number of species at Sagala (15 species) and Chawia (17 species).

Table 1. Tree species composition of Kizee Village Forest Reserve.

\begin{tabular}{|c|c|c|}
\hline Scientific name & Family & Potential use \\
\hline Albizia antihelmintica Brongn. & Fabaceae - Mimosoideae & Charcoal/ Poles \\
\hline Albizia glaberrina (Schumach \& Thonn) & Fabaceae - Mimosoideae & Firewood \\
\hline Acacia tortilis (Forsk.) & Leguminosae - Mimosoideae & Charcoal \\
\hline Afzelia quanzensis Smith (welw.) & Fabaceae & Charcoal/ Timber \\
\hline Alchornea laxflora (Benth) & Euphorbiaceae & Charcoal/ Timber \\
\hline Bersama abyssinica Roxb & Melianthaceae & Firewood/ Poles \\
\hline Bridelia micrantha (Hochst.) Baill & Euphorbiaceae & Firewood/ Poles \\
\hline Combretum schumanii Engl., & Combretaceae & Charcoal/ Poles \\
\hline Commiphora eminii Engl. ssp. & Burseraceae & Unknown \\
\hline Cordia monoica Roxb. & Boraginaceae & Poles \\
\hline Cussonia holstii Harms ex. Engl. & Araliaceae & Unknown \\
\hline Dombeya taylorii Baker.f., & Malvaceae & Charcoal/ Firewood/ Poles \\
\hline Dombeya burgessiae Gerr. & Sterculiaceae & Poles \\
\hline Grewia similis K. Schum., & Tiliaceae & Charcoal/ Poles \\
\hline Lannea schweinfurthii (Engl. var. stuhlmannii & Anacardiaceae & Charcoal \\
\hline Lecaniodiscus fraxinifolius Baker. & Sapindaceae & Charcoal/Firewood/ Poles \\
\hline Leucaena leucocephala Benth. & Fabaceae & Firewood/Fodder \\
\hline Lonchocarpus bussei Harms & Leguminosae & Charcoal/ Firewood/ Poles \\
\hline Manilkara sulcata (Engl.) Dubard. & Sapotaceae & Charcoal/ Firewood/ Poles \\
\hline Milicia excelsa Sim. (welw.) & Moraceae & Timber \\
\hline Sclerocarya birrea (A. Rich.) & Anacardiaceae & Charcoal/ Timber \\
\hline Securidaca longipendunculata Fres. & Polygalaceae & Unknown \\
\hline Sterculia appendiculata K. Schum & Sterculiaceae & Timber \\
\hline Stereospermum kunthianum Cham & Bignoniaceae & Firewood \\
\hline Tacca leontopetaloides (L.) O. & Dioscoreaceae & Firewood/ Poles \\
\hline Tamarindus indica L., & Fabaceae & Charcoal/ Timber/Fruits \\
\hline Teclea trichocarpa (Engl.), & Rutaceae & Charcoal/ Poles \\
\hline Terminalia kilimandischarica Engl. & Combretaceae & Charcoal/ Timber/ Poles \\
\hline Thespesia danis & Malvaceae & Poles \\
\hline
\end{tabular}

The stability of any community/ population is directly dependent on the diversity. The study findings revealed that, the forest's Shannon - Wiener diversity index was 2.2717 implying that the tree species diversity of the forest is just normal. The obtained results are within the good diversity range of 1.5 and 3.5 recommended by Kent and Coker [17]. The higher values of diversity indicate greater stability of community structure [18]. The good tree species diversity can be used to justify the good effort in conservation activities. When studying traditionally protected forest as a conservation area, Mndolwa [19] and Pima et al. [20] found that biodiversity indices indicated higher species diversity in the protected areas than in the non-protected areas and the diversity increases as you move from the boundary deep into 
the forest. This means the Kizee forest ecosystem is within the average of stability and communities living close to the reserve have affected the tree species diversity positively. Care is needed as any action which will involve removal of trees for timber, poles and fuelwood may result into change of this index. These changes may cause loss and changes in the flora [21] and gradual exploitation over time may cause forest degradation that will result into declining quality and supply of many forest products. This can also be reached by removal of the just few tree species, especially early successional sub canopy species.

\subsubsection{Species Dominance}

The forest was dominated by Albizia antihelmintica which consisted $19.83 \%$ of all species, followed by G. similis (17.63\%), L. fraxinifolius (10.74\%), M. sulcata (8.26\%), C. holstii $(7.44 \%)$, T. leontopetaloides $(4.68 \%)$ and $C$. eminii (4.68\%) (Fig. 1). The least species include A. quanzensis, $T$. indica, D. burgessiae, $S$. longipendunculata and $F$. sycomorus which contributed $0.28 \%$ each.

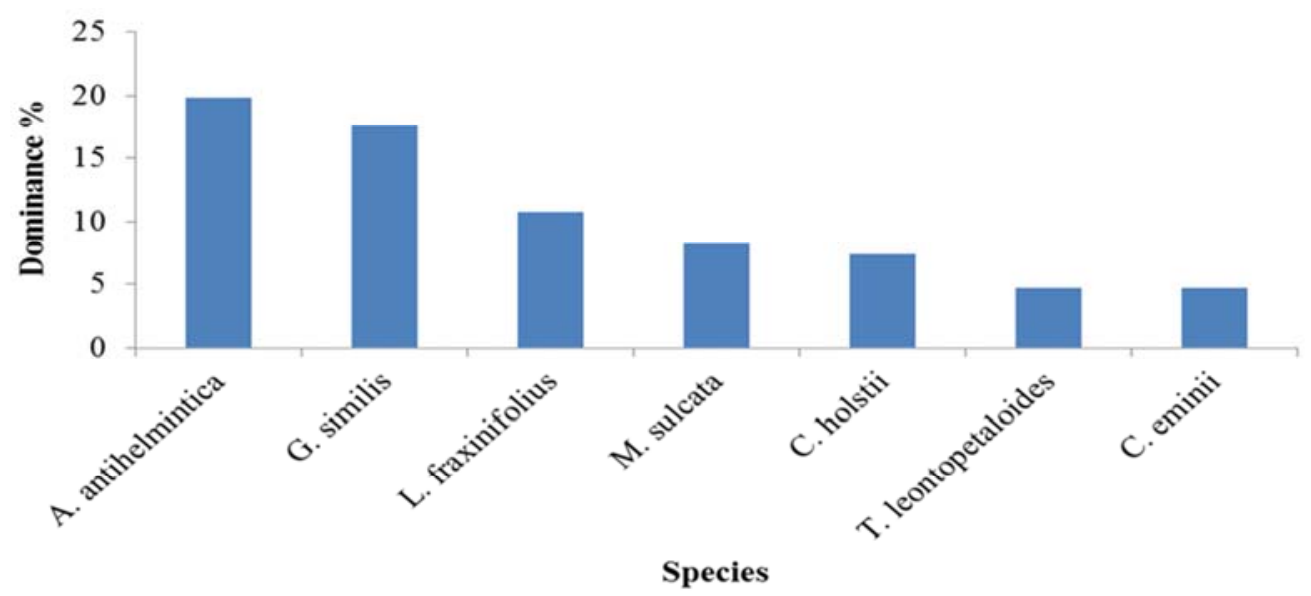

Figure 1. Percentages of mostly dominant tree species at Kizee Village Forest Reserve.

\subsubsection{Tree Species Diameter Distribution}

Fig. 2 represents diameter distribution of trees at KVFR. The stems frequency decreased with the increase in DBH and the distribution showed a reverse $J$ shape curve. This generally indicates that KVFR is developing and regeneration in the forest is good. Natural regeneration is dependent on the availability of mother trees, fruiting pattern and favourable conditions. As shown (Fig. 2), the presence of growth of the forest is indicated by the trend of trees in various diameter classes. With this situation generally, stems frequencies decrease with increase in DBH in all tree species. In this studied forest, higher number of stems for smaller diameter with $37 \%$ of trees fell within $5-10 \mathrm{~cm}$ followed by
$23 \%(10-15 \mathrm{~cm}), 12.3 \%(15-20 \mathrm{~cm}), 14 \%(20-25 \mathrm{~cm}), 7.2 \%$ $(25-30 \mathrm{~cm}), 6.5 \%(30-35 \mathrm{~cm})$ with other larger trees contributing only less than $1 \%$. The results are in line with those reported by Pima et al. [20] at Mbwebwe community based forest reserves. This type of diameter distribution follows the usual reverse $J$ shape which is an indication of good regeneration in the forests [22]. However, some abnormality was noted within diameter class $20-25 \mathrm{~cm}$ where, there were few trees at the lower scale $(15-20 \mathrm{~cm})$ than the higher one $(20-25 \mathrm{~cm})$. This was probably due to differences in tree species which is reflected by growth property or frequently removed ones for poles and for local construction.

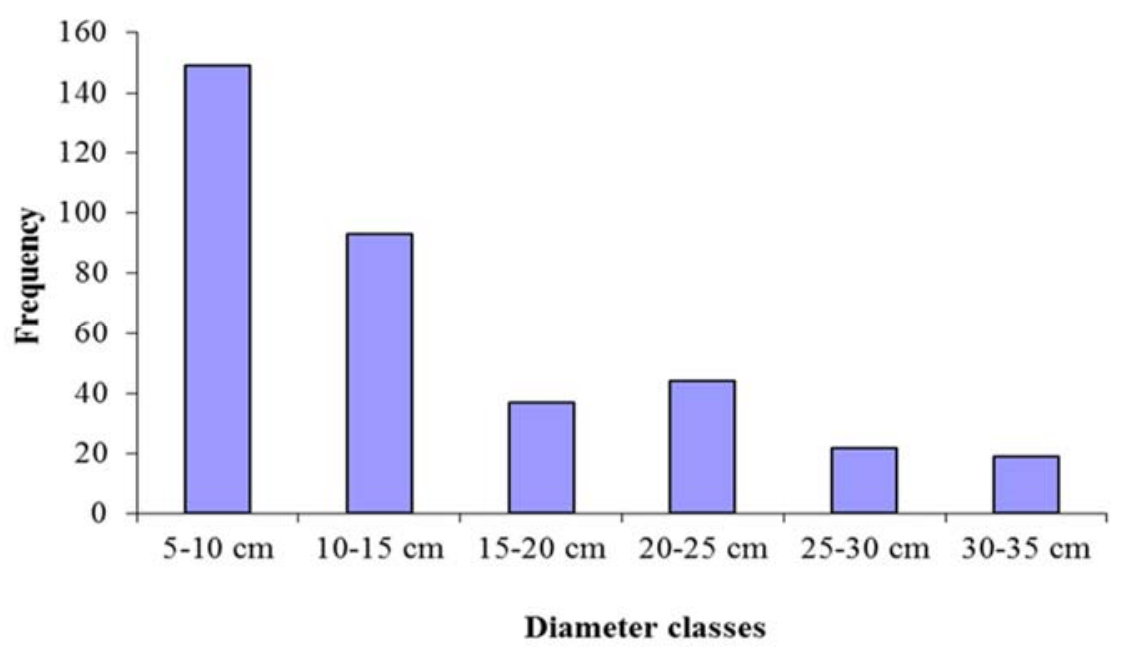

Figure 2. Diameter distribution of trees at Kizee Village Forest Reserve. 


\subsubsection{Tree Species Height Distribution}

Height distribution of trees at KVFR is as presented in Fig. 3. The forest is dominated $(63.1 \%)$ by trees of $4.5-9.5 \mathrm{~m}$ high. This is a very common phenomenon of the forest where very few tall trees which have reached climax can be found. The short trees might have also comprised of suppressed trees.

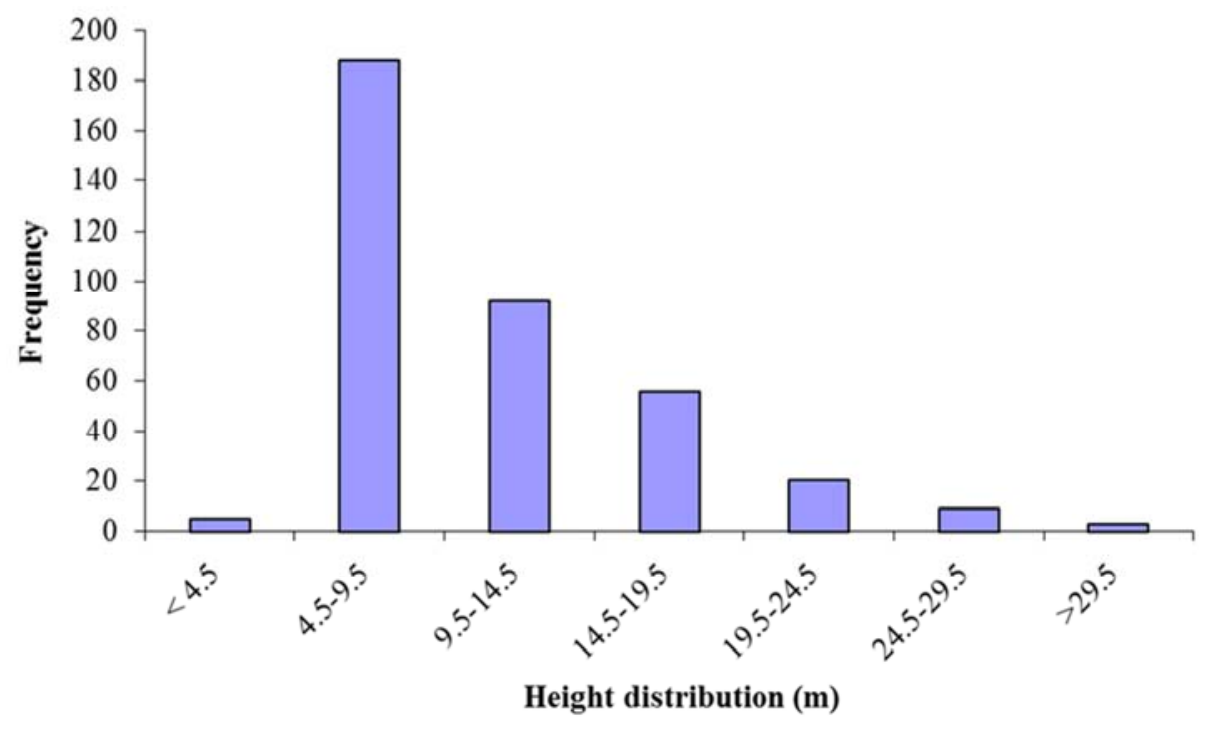

Figure 3. Height distribution of trees at Kizee Village Forest Reserve.

\subsubsection{Stem Density of Tree Species}

The stocking at KVFR was not very high. The forest had about 434 trees $\mathrm{Ha}^{-1}$. This is very close to the density reported by Wilder [16] when studying vegetation structure and composition of the Taita Hills Forests (297 stems - 578 stems $\mathrm{Ha}^{-1}$ at Chawia and Mbololo forests respectively). He also reported that other forests Ronge, Ngangao and Sagalla had 301 stems $\mathrm{Ha}^{-1}, 380$ stems $\mathrm{Ha}^{-1}$ and 386 stems $\mathrm{Ha}^{-1}$ respectively. The present results indicated that the forest is still good but some efforts are needed for the purpose of its maintenance and improvement.

\subsection{Awareness of the Forest Management System}

There was high degree of awareness where $80 \%$ of respondents were aware of the existence and management of the forest reserve (Table 2). It was found that villagers had different perceptions on the objectives of the forest conservation. Tourism was reported by many respondents $(35 \%)$ to be the major reason for conservation. Other reasons reported were weather amelioration (30\%), environmental conservation $(20 \%)$, conservation of animals and birds (15\%), other important factors which included water source and medicinal plants conservation was reported by only $5 \%$ of respondents (Table 2). It has been reported that the village environmental committee was responsible for forest patrol activities.

Seventy percent of the respondents were aware of types of trees available in the forest. The commonest species identified included Milicia excelsa, Afzelia quanzensis, Brachylaena huillensis and Albizia glaberrina. These were also the commonly removed trees from the forest. About
$50 \%$ of the respondents did not know if there were enough forest resources in the reserve. On the other hand, it was learnt that, $25 \%$ of the respondents indicated that there was very little resource while $25 \%$ agreed that the forest resource available was quite enough for local uses (Table 2). Villagers were aware of the existence of village by-laws. In this way the contribution of local communities' involvement in management of the resource turned to be a necessity with highly expected results. This is in line with the objectives set in the National Forest Policy [23] which insists on Participatory Forest Management in which the Community Based Forest Management (CBFM) is part.

Table 2. Awareness and perceptions of the forest management systems.

\begin{tabular}{ll}
\hline Parameter & \% Respondents \\
\hline Awareness & 80 \\
Aware on the existence and management of FR & 20 \\
Not aware on the existence and management of FR & \\
Perceptions on forest conservation & 35 \\
Tourism & 30 \\
Weather amelioration & 20 \\
Environmental conservation & 15 \\
Conservation of animals and birds & \\
Water source and medicinal plants conservation & \\
Awareness & 70 \\
Aware on the type of tree available & 30 \\
Not aware on the type of tree available & \\
Forest Resources & 50 \\
$\begin{array}{l}\text { Do not know if there are enough forest resources in } \\
\text { the reserve }\end{array}$ & 25 \\
Very little resources & 25 \\
Resources available to the forest &
\end{tabular}

\subsection{Tree Species and Their Potential Uses}

Seven potential uses of trees were reported (timber, 
charcoal, firewood, fodder, medicinal, poles and others). It was found that, $3.13 \%$ of the trees had single use, $18.75 \%$ two uses, $28.89 \%$ three uses, $43.75 \%$ four uses and $6.25 \%$ for both five and six uses. Similar results were obtained by Mndolwa et al. [5] at Kitulanghalo when evaluating tree species enumerated in plots by uses and benefits. The results further revealed that, $8 \%$ of tree species were suitable for timber, $59.4 \%$ for charcoal, $93.8 \%$ for firewood, $9.4 \%$ for fodder, $78 \%$ for local medicine, $53 \%$ for poles and $31 \%$ for other uses (Fig. 4). Other uses included dyes, tool handles, fibres and carvings. Harvesting of timber within Village Land Forest Reserves is surprisingly, a relatively new concept in Tanzania and a learning process for all involved [24].

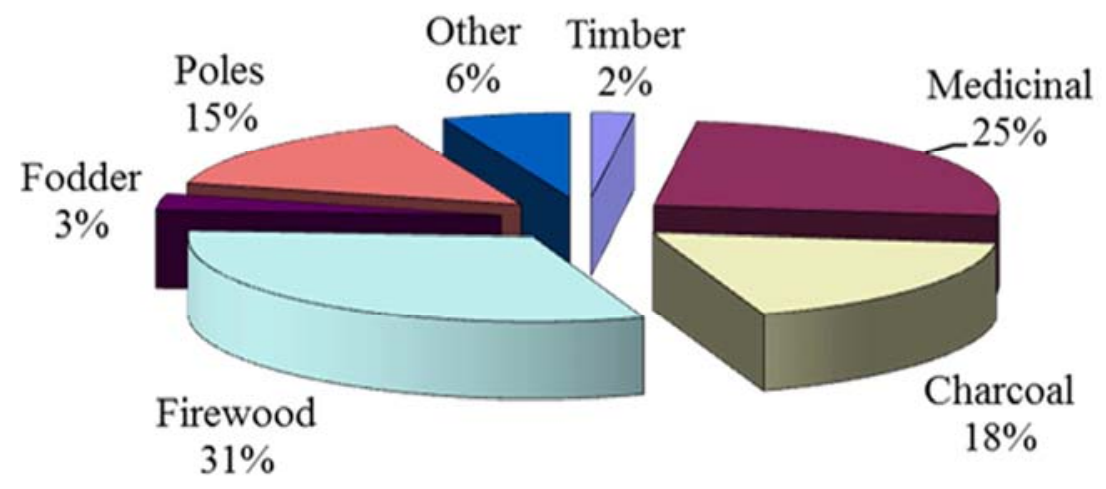

Figure 4. Percentage of trees and their potential uses at Kizee Village Forest Reserve.

The major timber tree species reported from the area were Sterculia appendiculata, Milicia excelsa, Afzelia quanzensis, Sclerocarya birrea sub. caffra, Terminalia kilimandischarica and Brachylaena huillensis. Other lesser used timber trees identified were Tamarindus indica and Alchomea laxiflora (Table 1). The present results showed typical situations where the formerly preferred timber trees were no longer available and the lesser preferred ones such as $S$. birrea sub species caffra and $S$. appendiculata were taken on board. In addition, the priority trees extracted for charcoal included Albizia antihelmintica, Lannea schweinfurthii, Acacia tortilis, A. polyacantha, Lecaniodiscus fraxinifolius, Manilkara sulcata, Milicia excelsa, Lonchocarpus bussei, Grewia similes (Table 1). Trees reported to be good source of fruit/fodder were $T$. indica (fruits) and L. leucocephala (fodder). All trees have been reported to have medicinal values except $D$. burgessiae, $L$. leucocephala, $C$. schumanii, T. kilimandiscarica, D. tylorii, Tacca leontopetaloides and M. sulcata. Similar results were reported by Shangali et al. [25] who found that traditional medicine is the leading trees use at Udzungwa forests. Priority trees reported for poles were Cordia monoica, $C$. schumanii and Albizzia antihelmintica (Table 1).

\section{Conclusions}

The results only gave light of what has to be expected in case a decision is reached to remove any of the tree species. The index obtained showed a relative achievement of forest policy of improved forest quality and stable forest community which needs more attention to make sure that the forest is not degraded. There is a need for close follow up of the boundaries around the KVFR to reduce chances for more anthropogenic activities.

\section{References}

[1] Langat, D. K., Maranga, E. K., Aboud, A. A. \& Cheboiwo, J. K. (2016). Role of Forest Resources to Local Livelihoods: The Case of East Mau Forest Ecosystem, Kenya. International Journal of Forestry Research 2016: 1- 10.

[2] Hassan, B. A. (2015). The Importance of Tree Resources in Rural Livelihoods in the Horn of Africa. Horn of Africa Journal. [http://afrikansarvi.fi/issue1/15-artikkeli/40-theimportance-of-tree-resources-in-rural-livelihoods-in-thehorn-of-africa].

[3] Sumbi, E. (2004). Community Perception of cost and benefits of different forest management approaches: A. case study of Udizungwa Mountain and Surrounding Miombo woodlands, Tanzania. A. thesis submitted in partial fulfillment of requirements for the degree of Master of Science in protected landscape management of the University of Wale, 93pp.

[4] MNRT. (2001). National Forest Programme in Tanzania 2001 - 2010. Ministry of Natural Resources and Tourism (MNRT) Dar es Salaam, 134pp.

[5] Mndolwa, M. A., Lulandala, L. L. L. \& Elisha, E. (2008). Evaluation of tree species enumerated in Kitulangalo Mitmiombo plots by uses and benefits. Working Papers of the Finnish Forest Research Institute 98: 5-9.

[6] Mbuya, L. P., Msanga, H. P., Ruffo, C. K., Birnie, A. \& Tengnas, B. (1994). Useful Trees and Shrubs for Tanzania. Identification, Propagation and Management for Agriculture and Pastoral Communities, SIDA, Regional Conservation Unit. 542 p.

[7] Rahayu, S., Lusiana, B., Amaruzaman, S., Hendrawan, D. C. \& Pambudi, S. (2015). Tree diversity and its use in Buol District, Indonesia. Working Paper 212. Bogor, Indonesia: World Agroforestry Centre (ICRAF) Southeast. [http://dx. doi. org /10.5716/WP15723. PDF]. 
[8] MEA (2005). Ecosystems and human well-being: biodiversity synthesis. Millennium Ecosystem Assessment. Washington DC: World Resources Institute.

[9] Johansson, S. G., Cunneyworth, P., Doggart, N. \& Botterweg, R. (1998). Biodiversity surveys in the East Usambara Mountains; Preliminary findings and Management implications. Journal of East African Natural History. Vol. 87: $139-157$.

[10] Hall, J. (2005). Biodiversity of a landscape: examining forest heterogeneity and ecological change in the East Usambaras of Tanzania. Working Forests in the Tropics - Small Grant Technical Report 2005.

[11] NAFORM. (1999). National Forestry Research Master Plan (NAFORM 2000 - 2009). Ministry of Natural Resources and Tourism, Forestry and Beekeeping Division. $61 \mathrm{pp}$.

[12] Chamshama, S. A. O., Mugasha, A. G. \& Zahabu, E. (2004). Stand biomass and volume estimation for Miombo Woodlands at Kitulangalo, Morogoro, Tanzania. Southern African Forestry Journal 200: 59-69.

[13] URT. (2012). Population and Housing Census-General Report. Tanzania National Websites. [http://www. Tanzania.go.tz/ census /tables. htm].

[14] Synnot, T. J. (1979). A. manual of permanent plot procedures for tropical rain forest. Tropical forest paper No. 14. University of Oxford. Pp $12-40$.

[15] Malimbwi, R. E., Zahabu, E. \& Monela, G. C. (2005). Charcoal potential of miombo woodland at Kitulangalo, Tanzania. Journal of Tropical Forest Science, 17:197-210.

[16] Wilder, C., Brooks, T. \& Lens, L. (1998). Vegetation Structure and Composition of the Taita Hills Forests. Journal of East African Natural History 87: 181 - 187.

[17] Kent, M. \& Coker, P. (1992). Vegetation Description and
Analysis. A. practical Approach. C. R. C Press, Boca Rotam Ann Arbor: Belhaven Press, London. 363 pp.

[18] Kohli, R. K., Singh, H. P. \& Rani, D. (1996). Status of floor vegetation under some monoculture and mix culture plantations in North India. Journal of Forest Research 1: 205 -209 .

[19] Mndolwa, M. A. (1999). Human impact on woody vegetation in Ruvu North Forest Reserve Tanzania. Dissertation for Award of MSc Degree at Sokoine University of Agriculture, Morogoro, Tanzania. 84pp.

[20] Pima, N. E., Madoffe, S. \& Munishi, P. K. T. (2013). Plant species composition in Zaraninge and Mbwebwe Coastal Forests, Bagamoyo District, Tanzania. Journal of Tanzania Association of Foresters 12: 1-9.

[21] Rao, M. B., Rao, P. N., Reddy, D. L., Rambabu, A. V. S. \& Prasad, B. V. (1987). Ecological changes in the tropical mangrove ecosystem due to human impact. Tropical Ecology 28(2): $232-238$.

[22] Nduwamungu, J. (1997). Tree and shrub species diversity in miombo woodlands. A case study at Sokoine University of Agriculture Kitulangalo Forest Reserve, Morogoro, Tanzania. Dissertation for Award of MSc Degree at Sokoine University of Agriculture, Morogoro, Tanzania. 175pp.

[23] National Forest Policy. (1998). Ministry of Natural Resources and Tourism. Government Printer, Dar es Salaam. 59pp.

[24] Lissu, T. A. M. (2007). Moving towards sustainable harvesting of village forests - experiences from Kiteto district - SULEDO Forest. The Arc Journal No. 21; 8 - 10.

[25] Shangali, C. F., Mabula, C. K. \& Mmari, C. (1998). Biodiversity and human activities in the Udzungwa Mountain Forests, Tanzania. Ethnobotanical Survey in the Uzungwa scarp Forest Reserve, Journal of East African Natural History Vo. 87: $291-318$. 